\title{
TEKNIK MENGHITUNG TELUR IKAN BUJUK (Channa lucius) DENGAN METODE GRAVIMETRIK
}

\author{
Mirna Dwirastina \\ Teknisi Litkayasa pada Balai Riset Perikanan Perairan Umum, Mariana-Palembang \\ Teregistrasi I tanggal: 26 April 2007; Diterima setelah perbaikan tanggal: 10 Mei 2007; \\ Disetujui terbit tanggal: 19 Nopember 2007
}

\section{PENDAHULUAN}

Ikan bujuk termasuk kerabat Channa yang hidup di air tawar terutama di lebak-lebak, hutan rawang, dan rawa banjiran. Ikan ini merupakan salah satu ikan yang menghasilkan telur (ovivar) dalam proses reproduksi. Jumlah telur (fekunditas) ikan sangat ditentukan oleh beberapa hal antara lain ukuran tertentu, spesies, umur, makanan, dan lain-lain.

Perhitungan telur baru dapat dihitung apabila ikan telah mencapai tingkat kematangan gonad III-IV. Pada tingkat kematangan tersebut bentuk telur dan struktur sudah cukup sempurna dan utuh. Fekunditas berguna untuk mengetahui proses reproduksi ikan bujuk.

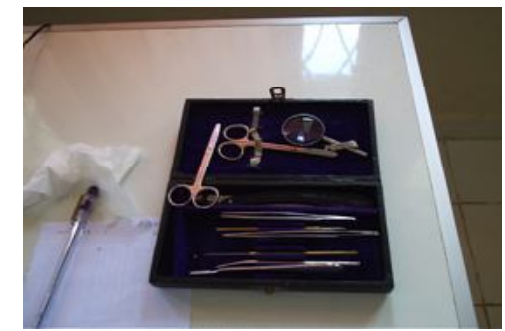

Gambar 1. Disecting set.
Tujuan dalam penulisan makalah ini adalah untuk memberi informasi cara menghitung telur ikan bujuk serta fekunditas ikan bujuk.

\section{POKOK BAHASAN}

Dalam proses menghitung telur ikan bujuk dibutuhkan beberapa hal antara lain:

\section{Alat dan Bahan}

Alat-alat yang digunakan adalah disectings set (Gambar 1), kertas saring, cawan petri, plastik, timbangan elektrik (Gambar 2), dan bahan yang digunakan adalah larutan gilson (Gambar 3), dan telur ikan bujuk. Alat dan bahan yang diperlukan dalam proses menghitung jumlah telur ikan bujuk (Channa lucius) sebagai berikut:

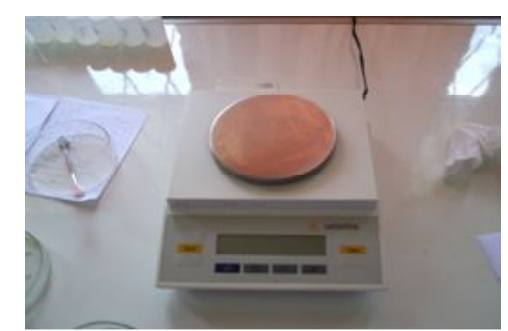

Gambar 2. Timbangan elektrik dan cawan.

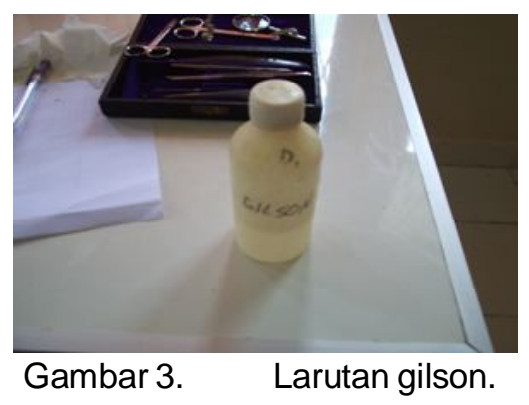

\section{Cara Kerja}

\section{Di lapangan}

Ikan bujuk yang diperoleh ditimbang bobot kemudian dibedah dengan menggunakan gunting kemudian telur diambil dan dimasukkan dalam kantung plastik, setelah itu di beri larutan gilson sampai telur terendam oleh larutan gilson. Sebelum diikat diberi label berisi keterangan tanggal, tempat, bobot, dan jenis ikan.

\section{Di laboratorium}

Langkah kerja di laboratorium adalah sebagai berikut:

1. Telur dalam kantong plastik dikeluarkan.

2. Telur tersebut dikeringkan dalam cawan petri yang dilapisi kertas saring.

3. Timbang bobot total telur, kemudian dilakukan perhitungan untuk sebagian telur, berdasarkan pada pembagian yang telah ditentukan yaitu pada tepi kanan, tengah, dan tepi kiri. Metode 
perhitungan dengan menggunakan gravimetrik karena jumlah telur banyak.

Rumus: $\mathrm{X}_{\mathrm{i}} \mathrm{x}=\mathrm{V}: \mathrm{V}$

di mana:

$X=$ jumlah telur yang akan dicari (butir)

$\mathrm{x}=$ jumlah telur dari bobot yang telah ditentukan (butir)

$\mathrm{V}=$ bobot telur dari seluruh gonad $(\mathrm{g})$

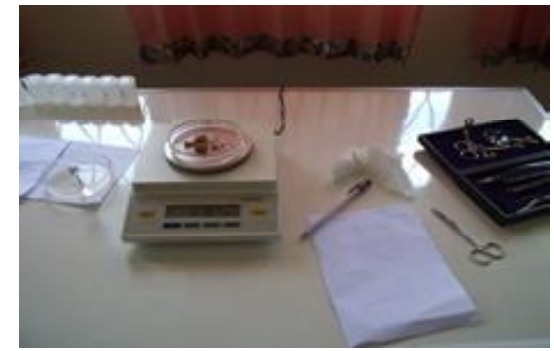

Gambar 4. Timbang bobot total telur.

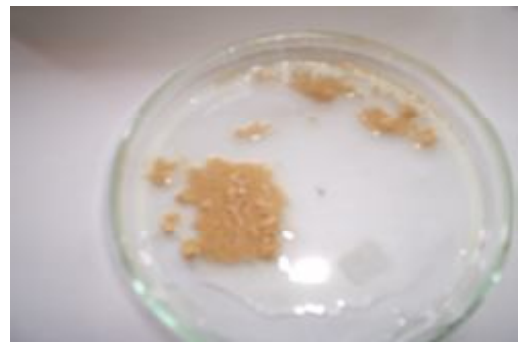

Gambar $6 . \quad$ Telur yang akan dihitung. $v=$ bobot telur-telur ikan yang telah diketahui (g)

Telur yang sudah ditimbang bobot dihitung menggunakan wadah cawan petri. Hitung jumlah telur tersebut (Gambar 6 dan 7) menggunakan jarum (needle set) pada disetting set (Effendie, 1975). Pada metode ini semua telur ikan yang dihitung diasumsikan bobot sama sehingga dapat menggunakan rumus di atas dalam perhitungan. Hasil perhitungan jumlah telur ikan bujuk (Channa lucius) tercantum pada Tabel 1.

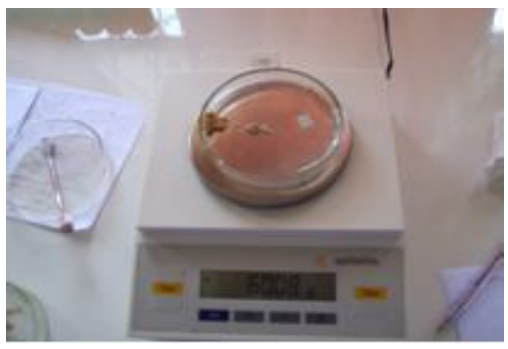

Gambar 5. Timbang setelah hasil pembagian.

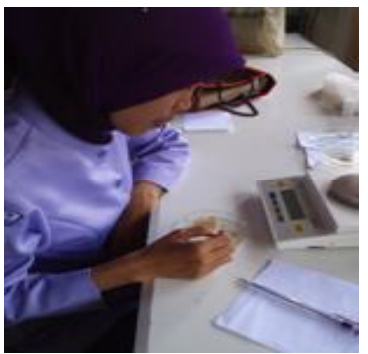

Gambar 7. Proses menghitung dan hasil dicatat.

Tabel 1. Hasil perhitungan jumlah telur ikan bujuk daerah Lebak Pasunde, Sumatera Selatan

\begin{tabular}{ccccc}
\hline No. & Nama ikan & $\begin{array}{c}\text { Bobot total } \\
(\mathbf{g})\end{array}$ & $\begin{array}{c}\text { Bobot dihitung } \\
(\mathbf{g})\end{array}$ & $\begin{array}{c}\text { Jumlah total telur } \\
\text { (butir) }\end{array}$ \\
\hline 1. & Ikan bujuk & 3,38 & 1,126 & 6.480 \\
2. & Ikan bujuk & 3,02 & 1,01 & 764 \\
3. & lkan bujuk & 4,64 & 1,54 & 1.950 \\
\hline
\end{tabular}

Sumber: Penelitian distribusi ikan Marga Channa (kerabat gabus) dan biologi reproduksi ikan serandang (Channa pleuropthalmus) di perairan daerah aliran Sungai Musi

Metode dalam menghitung telur ini adalah gravimetri. Pada tabel di atas diketahui bahwa bobot total $3,38 \mathrm{~g}$ menghasilkan jumlah telur 6.480 butir, bobot telur 3,02 g menghasilkan jumlah telur 764 butir, dan bobot telur 4,64 g menghasilkan jumlah telur 1950 butir. Perbedaan jumlah ini kemungkinan disebabkan perbedaan pada diameter telur dan tingkat kematangan gonad. Ikan bujuk pertama dan ikan bujuk kedua tingkat kematangan gonad mencapai tingkat 3, dan ikan bujuk 4 tingkat kematangan gonad IV.

\section{KESIMPULAN}

Dalam penulisan makalah ini dapat ditarik suatu kesimpulan sebagai berikut:
1. Metode gravimetrik digunakan bila jumlah telur ikan yang diamati kapasitas banyak.

2. Bahan pengawet telur berupa gilson sangat diperlukan untuk memudahkan menghitung telur.

3. Hasil perhitungan jumlah telur berguna untuk mendukung data fekunditas pada ikan tersebut. Jumlah telur ikan bujuk yang dihasilkan berkisar 764-6.480 butir.

\section{DAFTAR PUSTAKA}

Effendie, M. I. 1975. Metode Biologi Perikanan. Fakultas Perikanan. Institut Pertanian Bogor. 